\title{
Review on Guillain-Barre Syndrome in Pediatric Along with Consideration of Ayurvedic and Modern Aspects of Management
}

\author{
Dr. Shital Jadhav (Pg Scholar) (Kaumarbhritya) \\ Guided By :- Dr. Sudha Singh (M.D Kaumarbhritya), \\ Dr. Madhavi S Deodas \\ Guide \& H.O.D Department of Kaumarbhritya, College of Ayurved Akurdi-Pune
}

\begin{abstract}
:
Guillain-Barre syndrome (GBS) is an acute, rapidly evolving areflexic motor paralysis with or without sensory disturbance. It occurs year around at a rate of between 1 and 4 cases per 100,000 annually. Increasing data indicate that it is an autoimmune disease, often triggered by a preceding viral or bacterial infection with organisms such as Campylobacter jejuni, Helicobacter pylori, or Mycoplasma pneumoniae. Vaccination against the flu, rabies, and meningitis are also documented precipitating factors that have been reported. Investigations include Electromyography, CSF studies and serum CK levels. To date, treatment for GBS has been aimed primarily at immunomodulation (IVIG). Mamsa-Medogata Vata is the condition that can be categorized under GBS due to proximity of their clinical presentation.
\end{abstract}

\section{Introduction}

Guillain Barre Syndrome (GBS) describes a heterogeneous condition involving mainly motor but sometimes also sensory and autonomic nerves [1]. The classic presentation is characterized by an acute monophasic, non-febrile, post-infectious illness manifesting as ascending weakness and areflexia. With the eradication of poliomyelitis, GBS is the most common cause of acute motor paralysis in children.

The pathogenesis of GBS remains unclear. Increasing data indicate that it is an autoimmune disease, often triggered by a preceding viral or bacterial infection with organisms such as Campylobacter jejuni, Helicobacter pylori, or Mycoplasma pneumoniae. Vaccination against the flu, rabies, and meningitis are also documented precipitating factors that have been reported. [2]

The clinical diagnosis of GBS is typically based on the presence of a progressive ascending weakness with areflexia. Investigations include Electromyography, CSF studies and serum CK levels. To date, treatment for GBS has been aimed primarily at immunomodulation. In pediatrics, the most effective form of therapy is generally considered to be intravenous immunoglobulin (IVIG). In general, the outcome of GBS is more favorable in children than in adults; however, the recovery period is long, often weeks to months. Rarely, it can also be fatal in 5-10\% of patients with respiratory failure and cardiac arrhythmia. [3]

Exact correlation of any condition explained in Ayurveda cannot be made precisely with Guillain-Barre Syndrome. Mamsa-Medogata vata [4] is the condition that can be categorized under GBS due to proximity of their clinical presentation.

Management includes Snehan, Swedan, Mrudu Shodhan (Snigdha Ushna Basti) and use of Vataghna and Balya medicines.

Etiology

GBS is an autoimmune-mediated disease with environmental triggers (eg, pathogenic or stressful exposures). Several infections (e.g Epstein-Barr virus, cytomegalovirus, hepatitis, varicella, other herpes 
viruses, Mycoplasma pneumoniae,C jejuni) as well as immunizations have been known to precede or to be associated with the illness.

C jejuni seems to be the most commonly described pathogen associated with GBS.

Vaccinations

Regarding the concern of antecedent vaccinations, the US Centers for Disease Control and Prevention (CDC) has published retrospective data of the 1000 reported cases of known GBS from 1990-2005. The highest number of GBS cases was observed after an influenza vaccination $(n=632)$ and the second highest was after a hepatitis B vaccination ( $n=94)$. [5]

\section{SIGNS \& SYMPTOMS}

Areflexic motor paralysis with or without sensory disturbance. Weakness begins usually in the lower extremities and progressively involves the trunk, the upper limbs and finally the bulbar muscles. A pattern known as Landry ascending paralysis.

\section{Subtypes}

1. Acute inflammatory demyelinating poly radiculo neuropathy AIDP

2. Acute motor axonal neuropathy AMAN

3. Acute motor and sensory axonal neuropathy AMSAN

4. Miller fisher syndrome

Acute inflammatory demyelinating poly radiculo neuropathy (AIDP) is the most common form and accounts for around $85-90 \%$ of cases. The clinical features are of symmetrical ascending motor weakness with hypo- or areflexia. The underlying pathological process involves inflammation and destruction of the myelin sheaths surrounding peripheral nerve axons by activated macrophages. This leads to slowing and blockage of conduction within peripheral nerves causing muscle weakness. Severe cases may develop secondary axonal damage

Acute motor axonal neuropathy (AMAN) is more common has an association with precedent infection with Campylobacter jejuni. Clinical features are similar to AIDP but tendon reflexes may be preserved. Electrophysiological testing may distinguish from other variants as selective motor nerve and axonal involvement is demonstrated. In AMAN the pathological process involves binding of antibodies to ganglioside antigens on the axon cell membrane, macrophage invasion, inflammation and axonal damage.

Acute motor and sensory axonal neuropathy (AMSAN) is a variant of GBS in which both motor and sensory fibres are involved and which can be demonstrated on electrophysiological studies. It is more severe and associated with prolonged or even partial recovery. Clinical features are similar to AMAN but also involve sensory symptoms. The underlying pathological process is similar to that for AMAN (i.e. antibody mediated axonal damage).

Miller Fisher syndrome (MFS) presents with ataxia, areflexia and ophthalmoplegia. 25\% of patients may develop limb weakness. Electrophysiological studies show primarily sensory conduction failure. Antiganglioside antibodies to GQ1b are found in $90 \%$ of patients and are associated with ophthalmoplegia . There have been limited pathological studies in MFS but demyelination of nerve roots has been demonstrated.

\section{INVESTIGATIONS}

Antiganglioside antibodies :

Anti-GM1 - It is positive in $25 \%$ of pts and is a worse outcome

Anti-GD1a • AMAN subtype of GBS

Anti-GQ1b • Miller- Fisher syndrome

Infection screen : 
Sireesha Kalva ${ }^{1}$, International Journal of Ayurvedic \& Herbal Medicine 8(1) Jan.-Feb. 2018 (3089-3093)

Campylobacter jejuni, Cytomegalovirus, Epstein-Barr virus, Herpes simplex virus, Mycoplasma pneumoniae. HIV antibodies

Radiological: MRI of the spine may show selective anterior spinal nerve root enhancement with gadolinium and will exclude cervical nerve impingement

\section{MANAGEMENT}

\section{MODERM CONSIDERATIONS:-}

1. Supportive

2. Immunomodulatory

Supportive:- Airway and Respiratory, Cardiovascular, Gastrointestinal, Neurological Psychological, and Rehabilitation.

Immunomodulatory:- Intravenous immunoglobulin - most effective if administered within two weeks of the onset of symptoms - Indications for IVIg include $\bullet$ muscle weakness and $\bullet$ respiratory depression

IVIG contains pooled donor Ig $\mathrm{G}$ antibodies and may reduce the severity of autoimmune inflammation in GBS by blocking Fc receptors. This prevents the Fc portion of antibodies binding and thus interrupts antibody mediated cell destruction. Complement activation is also altered.

Recommended dose:- IVIG $0.4 \mathrm{gm} / \mathrm{kg} /$ day for 5 consecutive days.

$2 \mathrm{~g} / \mathrm{kg}$ of IVIG given as a single dose or $1 \mathrm{~g} / \mathrm{kg} / \mathrm{d}$ over 2 days in children who are showing rapid signs of deterioration.

Plasma exchange- The aim of plasma exchange is to remove antibodies associated with the underlying autoimmune response passage of blood through an extracorporeal cell separator. The plasma fraction of the blood is removed then and replaced with FFP or human albumin solution. Anticoagulants are administered during the procedure.

Corticosteroids are not recommended for the management of GBS.

\section{PROGNOSIS}

Most patients with GBS recover fully but this may take many months of intensive therapy, although some are left with residual weakness. Bulbar and respiratory muscle involvement may lead to death if the syndrome is not recognized and treated. Although prognosis is generally good with majority of children recovering completely, three clinical features are predictive of poor outcome with sequelae, cranial nerve involvement, intubation and maximum disability at the time of presentation.

\section{Ayurvedic considerations for GBS:-}

\section{Mamsagata Vata / Medogata Vata}

$$
\begin{aligned}
& \text { गुर्वड्गनं तुध्यतेत्यर्थर्थ दण्डमुप्टिहतं यथा। } \\
& \text { सरुक् श्रमितमत्यर्थं मा.समेदोगतेऽनिले॥\{च.चि\} [7] }
\end{aligned}
$$

When the morbid Vata afflicts Mamsa (muscles / flesh) and / or Meda (fat tissue) the below said symptoms are seen:

- Gurvangam - Heaviness of the body

- Ati toda - Pricking / tingling in the body (muscles)

- Dandamushti hatam yatha - Feeling as if someone has hit with a closed fist or a stick

- Saruk - Pain

- Shramitam - Weakness

- Myelin sheath is a fatty white substance that surrounds the axon of some nerve cells, forming an electrically insulating layer. It is essential for the proper functioning of nervous system. This is damaged in GBS. This can be compared to Medogata Vata i.e. the vitiated Vata owing to its property 
Sireesha Kalva ${ }^{1}$, International Journal of Ayurvedic \& Herbal Medicine 8(1) Jan.-Feb. 2018 (3089-3093)

of dryness and roughness destroys the fat (myelin in this context). This will impact the conductivity of nerve signals at their synapse with muscle fibres. The muscles get weak and lead to GBS.

\section{External considerations of treatment :-}

1) ABHYANGA :- Bala-ashwagandha lakashadi thaila or Chandanbala lakshadi taila [8]

\section{2) SHASTIKASHALIPINDASWEDA.}

- Abhyanga (oleation therapy) mitigates Vātadoṣa act gives Pușți (promotes strength). Doṣa involved is Vâta and the disease is caused due to the reduction in its Chalaguna causing inability to transmit nerve impulses.

- All ingredients of the Shashtikashalipindasweda such as Kshira, Shashtikashali , and Balamoola possess Santarpana (nourishing) qualities with Prithwi and Ap Mahabhuta and is indicated for Balya, Bruhana, and strengthening of Dhatus and Vata pacification.

- Hence snehana and swedana facilitates opening up of blocks in nerve conduction and facilitates remyelination of nerves; thereby helps transmit nerve impulses with minimum amount of stimulus for muscularcontractions.

3) BASTI :-Taking Pakwashaya as Moola sthana for the Vatavyadhi , Matrabasthi with Mahakalyanakaghritha can be considered .

Also,

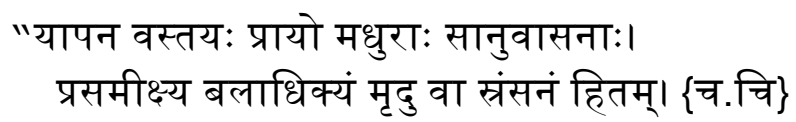

- Yapana Vasti - Nourishing enemas

- Madhura Anuvasana Vasti - Enemas with oils and ghee processed with drugs having sweet taste

- Mrudu sramsanam - Mild laxatives (after judging the strength of the patient)

Nourishment Of Nerves Is Also Important. Considering All The Above Facts Sutshekhar Rasa [9], Guduchi Satva [10,11, 12] And Bruhat Vata Chintamani Rasa Can Be Used [13].

Attack of immune system- Tîkṣnaguna of pitta along with shighra guna of vata at immune system level bring about mis judgement and hypersensitivity and causes destruction of the body tissue and we can postulate that this is how autoimmune disorders occur.

Hence consideration of tikshna guna of pitta [14] and its treatment is very important while treating various autoimmune disorders. Caraka has also stated importance of kshir in the treatment of vatpittaja jvara. Hence pittaghna dravya siddha kshir basti can be used.

Vata pittaghana chikitsa is important in treatment of autoimmune disorders. Various vata pittaghana dravyas can be used according to samata or niramata in the treatment of autoimmune disorders.

Sutshekahara rasa is a drug which classically acts on pitta while guduchi and raupya bhasma acts on majja dhara kala. Ayurvedic concept of pittadhara kala - majja dhara kala sahacharya also shows resembalance with molecular mimicry theory for C. Jejuni and nerve involvement in GBS pathology.[15]

\section{Conclusion}

From the above discussion, it is clear that Vata dosha is important in the samprapti of GBS. Therefore, it is important to control the vitiated dosha to enhance complete and early recovery of the weakness. The article also opens a new research window in the field of Ayurvedic to observe the effect of treatment in newer form of diseases in which Modern science has no definite line or treatment. 
Sireesha Kalva ${ }^{1}$, International Journal of Ayurvedic \& Herbal Medicine 8(1) Jan.-Feb. 2018 (3089-3093)

References:-

1. Longo DL, Fauci AS, Kasper DL, Jameson JL, Hauser SL, Loscalzo J. Vol. 2. New York, NY: McGraw Hill; 2010. Harrison's Principle of Internal Medicine; p. 3473.

2. Harve B Sarnat, Vol. 2, 2008, Nelson textbook of pediatrics, 18 th edition; p 2565

3. Lee JH, Sung IY, Rew IS. Clinical presentation and prognosis of childhood Guillain-Barré syndrome. $J$ Paediatr Child Health. 2008 Jul-Aug. 44(7-8):449-54. [Medline].

4. Tripathi R. Charak Samhita of Charaka, Chikitsasthan, Vatvyadhi Chikitsa. Varanasi: Chaukhamba Sanskrit Series; 2009. p. 693.

5. Souayah N, Nasar A, Suri MF, Qureshi AI. Guillain-Barré syndrome after vaccination in United States: data from the Centers for Disease Control and Prevention/Food and Drug Administration Vaccine Adverse Event Reporting System (1990-2005). J Clin Neuromuscul Dis. 2009 Sep. 11(1):1-6.

6. Tripathi R. Charak Samhita of Charaka, Chikitsasthan, Vatvyadhi Chikitsa. Varanasi: Chaukhamba Sanskrit Series; 2009. p. 701.

7. Tripathi R. Charak Samhita of Charaka, Chikitsasthan, Vatvyadhi Chikitsa. Varanasi: Chaukhamba Sanskrit Series; 2009. p. 693.

8. Mishra SN. Bhaishajya Ratnavali of Govindadas Sen, Jwaraadhikar. Varanasi: Chaukhamba Sanskrit Series; 2007. p. 218..

9. Amlapitta Chikitsa Shlok 1-5. Varanasi: Chaukhamba Sanskrit Series; 2010. Bhisagratna and Brahmasankar Sastri Yogratnakar; p. 244.

10. Shastri A. Chapter 4, Verse 16. Varanasi: Dalhan Commentary Chaukhamba Sanskrit Series; 2007. Sushrut Samhita of Sushruta Sharir Sthan, Garbhavyakaran; p. 59.

11. Singh SS, Pandey SC, Srivastav S. Chemical and medicinal properties of tinospora cordifolia. Indian J Pharmacol. 2003;35:83-91.

12. Krishna KL, Bhatt J, Patel J. Guduchi (Tinospora cordifolia): Biological and medicinal properties, a review. Internet J Altern Med. 2009;6:10-5.

13. Mishra SN. Bhaishajya Ratnavali of Govindadas Sen Vatvyadhirogaadhikar. Varanasi: Chaukhamba Sanskrit series; 2007. p. 530.

14. Joshi YG. Charak Samhita of Charaka, Vimansthan Rogbhishakjitiyaviman. Chapter 8, Verse 97-98. Pune: Vaidya Mitra Publications; 2003. p. 599.

15. Longo DL, Fauci AS, Kasper DL, Jameson JL, Hauser SL, Loscalzo J. Entitled “GBS”. Part 17, Chapter 385. II. New York, NY: McGraw Hill; Harrison's Principle of Internal Medicine; p. 3477. 